NBER WORKING PAPER SERIES

\title{
AND NOW FOR SOMETHING COMPLETELY DIFFERENT: THE VERSATILITY OF CONCEPTUAL INNOVATORS
}

\author{
David W. Galenson \\ Working Paper 12034 \\ http://www.nber.org/papers/w12034 \\ NATIONAL BUREAU OF ECONOMIC RESEARCH \\ 1050 Massachusetts Avenue \\ Cambridge, MA 02138 \\ February 2006
}

The views expressed herein are those of the author(s) and do not necessarily reflect the views of the National Bureau of Economic Research.

(C)2006 by David W. Galenson. All rights reserved. Short sections of text, not to exceed two paragraphs, may be quoted without explicit permission provided that full credit, including $\odot$ notice, is given to the source. 
And Now for Something Completely Different: The Versatility of Conceptual Innovators David W. Galenson

NBER Working Paper No. 12034

February 2006

JEL No.

\begin{abstract}
$\underline{\text { ABSTRACT }}$
Art scholars have puzzled over the behavior of Pablo Picasso, Gerhard Richter, and Sigmar Polke important modern painters who have made frequent and abrupt changes of style. Yet in each case the scholars have assumed this behavior to be idiosyncratic, and have consequently failed to recognize its common basis. Versatility is in fact often a characteristic of conceptual innovators, whose ability to solve specific problems can free them to pursue new goals. This contrasts sharply with the practice of experimental artists, whose inability to achieve their goals often ties them to a single style for a whole career. The phenomenon of the conceptual innovator who produces diverse innovations is an important feature of twentieth-century art; Picasso was the prototype, and he was followed by a series of others, from Marcel Duchamp through Damien Hirst. Versatility has furthermore been a characteristic not only of modern conceptual painters, but also of conceptual innovators in other arts, and conceptual scholars. Recognizing the common basis of this behavior increases our understanding of human creativity.
\end{abstract}

David W. Galenson

Department of Economics

University of Chicago

1126 East 59th Street

Chicago, IL 60637

and NBER

galenson@uchicago.edu 
$\underline{\text { Introduction }}$

I immediately distrust anybody trying to detect patterns of that sort in art, especially in terms of economics.

Art historian Robert Rosenblum, $1998^{1}$

In recent decades, it has become fashionable for scholars of art history to disdain systematic comparison or generalization. Much recent scholarship in the discipline considers one artist, or even one work, at a time. It was in recognition of this that an art historian, Robert Jensen, recently observed that members of his discipline have "lost the capacity to generalize about the whole history of art."' I believe that art historians' unwillingness, or inability, to carry out systematic comparative analyses has often led to a failure to recognize and understand important patterns of artistic behavior. This paper examines a striking example of such a failure, in which a form of creative behavior that became important in the twentieth century has been neglected because every instance of it has been treated as idiosyncratic.

The following section of this paper documents an observation that art historians have made about what they consider a puzzling practice of modern painters. Specifically, in three separate instances, a scholar commented on the behavior of a single painter, then attempted to explain the behavior by considering only that one artist. Although the observation was precisely the same in all three cases, the scholars were different in each case, the artist in question was also different, and none of the scholars showed any awareness of any other instance of this observation. My contention is that the failure to recognize the commonality of the artistic behavior at issue precluded satisfactory explanation of it. The practice noted by the scholars is in fact not unique to any artist, but rather is characteristic of a class of artists. The general 
explanation for the three painters' behavior is both simpler and more powerful than explanations that appeal to individual idiosyncrasy. Understanding this explanation furthermore allows us to recognize the same phenomenon in other arts, and in scholarship.

The One-Man Group Exhibition: Three Episodes

In 1985, the eminent art historian Meyer Schapiro began an essay titled "The Unity of Picasso's Art" with the following observation:

Picasso's art presents itself to us today as an example of a lifework that one cannot describe in terms of any single set of characteristics. If the works of Pablo Picasso were not identified directly with his name, if they were shown together in a big exhibition, it would be rather difficult to say that they were the work of one man. ${ }^{3}$

In 1996, the art historian David Campbell opened a paper titled "Plotting Polke"with the following observation:

One of the most intriguing aspects of Sigmar Polke's work is the way it defies attempts to read it as a unified project. So marked is the sense of aesthetic and thematic disjuncture in the work that visiting a Polke exhibition is often like wandering around a group show. ${ }^{4}$

And in an article written in 2002, the philosopher and critic Arthur Danto observed that Gerhard Richter "seems to vacillate between realism and abstraction, or even between various styles of abstraction, often at the same time." He then continued: "These vacillations seemed to me so extreme when I first saw a retrospective of Richter's work in Chicago in 1987, that it looked like I was seeing some kind of group show." ${ }^{5}$

It is striking that three different observers, writing about three different artists, all used exactly the same metaphor, of a one-man exhibition that appeared to be a group show. In all three 
cases, furthermore, the phenomenon of an artist producing unrelated works was not merely a puzzling practice involving appearances, but raised deeper problems for the observers. For

Schapiro, it raised the question of whether Picasso was serious:

There exists in his practice a radical change with respect to the very concept of working, of production. Working involves, at least within our tradition, the commitment to a necessary way of working. If you can work in any other way your please, then no one way has a necessity; there is an element of caprice or arbitrariness of choice. ${ }^{6}$

Campbell made a similar observation:

As a result of this aesthetic mobility, doubts arise about his artistic integrity... This reaction, no doubt anticipated by Polke, has the unfortunate consequence of questioning the control, conviction, and seriousness of his artistic programme. ${ }^{7}$

And Danto also made a similar comment:

For most artists in America, it is important that they be stylistically identifiable, as if their style is their brand. To change styles too often inevitably would have been read as a lack of conviction. ${ }^{8}$

In the essays I have quoted, Schapiro, Campbell, and Danto all proceeded to discuss the problem they identified, of why an artist would work in multiple styles, and all offered explanations. It is not my concern here to evaluate those explanations, except to note that each concentrated on the work and practice of the single artist under consideration, without systematic comparison or examination of the work of any other artist. I believe that these explanations cannot allow us to understand the basic source of the variety of styles used by each of the three artists, nor can they allow us to resolve satisfactorily the question of these artists' integrity. For I believe that there is a general explanation for these three cases, that also applies to the work and practices of many other artists. 


\section{$\underline{\text { Conceptual Innovators }}$}

The practice of an artist working in multiple styles is a characteristic of a number of conceptual innovators. This is a class of artists whose work is intended to communicate their emotions or ideas. Conceptual painters often plan their works carefully, to carry out specific goals. In a general description of conceptual innovators, I wrote the following:

Because their goals are precise, conceptual artists are often satisfied that they have produced one or more works that achieve a specific purpose. Unlike experimental artists, whose inability to achieve their goals often ties them to a single problem for a whole career, the conceptual artist's ability to be satisfied that a problem has been solved can free him to pursue new goals. The careers of some important conceptual artists have consequently been marked by a series of innovations, each very different from the others. ${ }^{9}$

Picasso, Polke, and Richter are all examples of important conceptual innovators who have made more than a single significant contribution.

Table 1 presents the distribution over the three artists' careers of all the illustrations of their work contained in a large number of survey textbooks of art history. This shows that Picasso and Polke both fit the pattern most common to conceptual innovators, of producing their most important contributions early in their careers. For Picasso this was the invention of Cubism in 1907, at the age of 26. Art historians have analyzed in detail the sources of Cubism, as Picasso synthesized elements taken from African art, early Iberian sculpture, and the paintings of

Cézanne and Gauguin. ${ }^{10}$ Yet the synthesis was a revolutionary one, for it changed the purpose of painting. As John Berger observed, with Cubism

The concept of painting as it had existed since the Renaissance was overthrown. The idea of holding up a mirror to nature became a nostalgic one... Painting became a schematic art. The painter's task was no longer to represent or imitate what existed... The 
metaphorical model of Cubism is the diagram: the diagram being a visible, symbolic representation of invisible processes, forces, structures. ${ }^{11}$

Thus the young Picasso pioneered a conceptual form of art in which the artist would no longer present visual descriptions of objects, but would instead symbolize his knowledge of them.

Polke's most important contribution was the invention of German Pop art in 1963, when he was 22 years old. Polke's early Pop works were influenced by illustrations of paintings by Warhol and Lichtenstein that he saw during 1962-63. He followed Warhol in taking images from magazine photographs, and like Lichtenstein he constructed these images by mimicking the benday dots that form photographs in newspapers and magazines. But Polke adapted both of these devices to his own purposes, as he avoided the glamorous individuals and sensational events chosen by Warhol in favor of more pedestrian subjects, and he gave greater emphasis than Lichtenstein to the benday dots, thus making the photographic images of his paintings compete with the patterns created by the irregularly colored dots. The result was recognizable as Pop art, but in a form distinctively different from those of the American artists. ${ }^{12}$ Yet German Pop art shared its conceptual basis with its older American relative, as it used mechanical reproduction, or its appearance, to recreate images drawn from popular culture.

Richter's career pattern is quite different. The absence of any illustrations of his work prior to the age of 30 is understandable as a consequence of his delayed exposure to advanced art. Richter was born and raised in East Germany, and his early studies in art were done there. His first opportunity to study advanced art did not occur until he moved to West Germany in 1961. When he enrolled in the Düsseldorf Kunstakademie in that year he was 29, nine years older than his classmate Polke. He joined Polke in creating German Pop art in 1963, while both were still 
students.

The early innovations of conceptual innovators are generally formal ones, based not on observation of nature but rather on the synthesis of earlier artists' work. This was true of Picasso's early innovations in Cubism, and of Polke's and Richter's early Pop art. In some cases, however, conceptual artists later make innovations that embody social or political statements. Picasso made a landmark innovation of this kind in 1937, at the age of 56, in Guernica, which responded to the destruction of the Basque town of Guernica by German bombers during the Spanish Civil War. Richter produced one of his most controversial bodies of work in 1988, at the age of 56, in 15 paintings based on photographs of members of the urban guerilla BaaderMeinhof group, three of whom died in a German prison in $1977 .{ }^{13}$

Picasso declared that "I paint objects as I think them, not as I see them."14 Richter equally expressed his belief in the conceptual nature of art, writing to a friend that "Pictures are the idea in visual or pictorial form." Richter often paints from photographs, and he explained that this eliminates the need to make decisions in the process of executing his works: "When I paint from a photograph, conscious thinking is eliminated." The image was predetermined and preconceived: "by painting from photographs, I was relieved of the need to choose or construct a subject." 15

Integrity and Style

In questioning the seriousness or integrity of these conceptual artists, Schapiro, Campbell, and Danto followed a number of earlier observers. As early as 1921, the German artist Oskar Schlemmer wrote to a friend that he had just seen a book that surveyed Picasso's career: "I was amazed at the versatility of the man. An actor, the comic genius among artists? For everything is 
there: he could easily assume the role of any artist of the past or of any modern painter."16

Interestingly, however, in the same year the painter and critic Amedée Ozenfant had specifically

explained Picasso's practice. Writing in a Paris journal, Ozenfant remarked on the clarity of

Picasso's intent, and the precision with which he expressed himself:

When he paints a picture, he knows what he wants to say and what kind of picture will in fact say it: his forms and colors are judiciously chosen to achieve the desired end, and he uses them like the words of a vocabulary.

Continuing the parallel between plastic forms and language, Ozenfant responded to critics who believed that Picasso's execution of representational works meant that he had repudiated Cubism:

Can such people not understand that Cubism and figurative painting are two different languages, and that a painter is free to choose either of them as he may judge it better suited to what he has to say? ${ }^{17}$

Ozenfant anticipated the concerns of Schapiro, Campbell, and Danto, and his response to them was to explain the attitude of the conceptual artist who is free to change forms and styles as he changes problems. Implicitly, these three observers were all judging the conceptual artists in question by the standard of experimental artists. ${ }^{18}$ A colleague of Campbell's, writing in the same symposium, did this explicitly, comparing Polke's practice with that of the experimental Abstract Expressionists:

[Polke] signals no single-minded commitment to a worthy programme (such as the pursuit of pure painterliness associated with American Abstract Expressionism, the paradigmatic intentionality of post-war avant-gardes). Critics who are primed to look for evidence of such integrity of purpose, of prolonged "struggle" with an heroic problematic, find none in Polke, and may assume therefore that he is opportunistic and undiscriminating. ${ }^{19}$ 
The conceptual Picasso's ability to choose styles to fit his changing ideas could not have differed more from that of an experimental painter like Cézanne, who undertook a lifelong quest to create a style that would allow him to achieve a single goal, and the same is true of the conceptual Polke and Richter in comparison with the experimental de Kooning or Rothko. ${ }^{20}$ These conceptual artists' periodic alternation of styles, like their rapid development of new styles over the course of their careers, reflected the basis of their art in ideas that could be formulated and expressed quickly, whereas the experimental artists' steadfast commitment to a single style, that could evolve only gradually over time, was a product of the visual nature of their art, and the impossibility of fully achieving their elusive goals. It is critical to recognize that rapid changes of approach and style, which would signal insincerity on the part of an experimental artist, can be signs of vitality for conceptual innovators.

\section{$\underline{\text { Picasso as Prototype }}$}

A succession of critics and scholars have commented on Picasso's frequent and sudden changes of style. As early as 1920, when Picasso was not yet 40 years old, Clive Bell remarked that "His career has been a series of discoveries, each of which he has rapidly developed. A highly original and extremely happy conception enters his head... Forthwith he sets himself to analyze it... Before long he has established what looks like an infallible method for producing an effect of which, a few months earlier, no one had so much as dreamed." ${ }^{21}$ In 1928, the German critic and poet Carl Einstein recognized that Picasso was a "pluralistic spirit," who could not be constrained by any single method, but who worked in a "polyphony of styles." Einstein described Picasso as "a man who has blown apart, as none other has, the limitations, the obsessional narrowness, of the practices of art."22 Decades later John Berger observed that Picasso's work 
was made up of "sudden inexplicable transformations," and declared that "In the life work of no other artist is each group of works so independent of those which have just gone before, or so irrelevant to those which are to follow." ${ }^{, 3}$ Pierre Cabanne made the same point by contrasting Picasso and Cézanne: "There was not one Picasso, but ten, twenty, always different, unpredictably changing, and in this he was the opposite of a Cézanne, whose work... followed that logical, reasonable course to fruition. ${ }^{24}$ Meyer Schapiro remarked on a consequence of Picasso's changes: “There is no example in all history of another painter who has been able to create such a diversity of works and to give them the power of successful art." ${ }^{25}$

Art scholars have been struck, however, not only by the fact that Picasso frequently changed styles, but that he often alternated between two styles, using two very different manners to make different works at the same time. Thus Schapiro remarked that in 1921, "In the morning he made Cubist paintings; in the afternoon he made Neoclassical paintings." In a recognition similar to that of Ozenfant, Schapiro then observed: "So that for him the two styles were both available and belonged to two different aspects of his personality." ${ }^{26}$ Jack Flam later echoed Schapiro, noting that "As early as 1915 Picasso had begun making meticulously rendered realistic drawings, and by the early 1920s he was alternating between a full-blown neoclassical style and more planar and abstract Synthetic Cubist imagery." ${ }^{27}$

What was startling about Picasso's practice was not simply that he made significant changes in style: Schapiro pointed out, for example, that in the 1880s an English writer had remarked that major works Raphael had made a decade apart could have been by different artists. ${ }^{28}$ What was novel in Picasso's approach was the frequency of his changes, and his ability to shift back and forth between styles. Flam reflected on the latter: 
Picasso was able effectively and convincingly to employ conflicting styles at will, and he used these with great energy another instance of his uncommon sensitivity to the arbitrariness of different languages. In fact, he was probably the first Western artist to insist willfully and persistently on the relative arbitrariness of the means of pictorial representation. ${ }^{29}$

Picasso thus appears to mark a turning point, for the first time using stylistic change as a strategy, a systematic practice that he used to achieve multiple goals. The English critic David Sylvester recognized this when he explained in 1996 why Picasso himself had been the key problem facing critics in the twentieth century: "Picasso is a kind of artist who couldn't have existed before this century, since his art is a celebration of this century's introduction of a totally promiscuous eclecticism into the practice of art." ${ }^{{ }^{30}}$ In a century marked by a heightened demand for innovation in art, Picasso's demonstration of how an individual artist could innovate frequently and radically became an inspiration for some of the most imaginative conceptual artists who came after him.

In a rare extended interview he gave to a friend in 1923, Picasso expressed his belief that the artist was free to choose styles as he wished, because styles were no more than forms of communication. Thus he declared that "We all know that Art is not truth. Art is a lie that makes us realize truth... The artist must know the manner whereby to convince others of the truthfulness of his lies." He explained that he chose styles that suited the problem at hand: "If the subjects I have wanted to express have suggested different ways of expression I have never hesitated to adopt them... Whenever I had something to say, I have said it in the manner in which I have felt it ought to be said. Different motives inevitably require different methods of expression." One key consequence of this he stressed was that changes in an artist's style should not be interpreted as 
growth or improvement, but should be recognized merely as a succession: "Variation does not mean evolution. If an artist varies his mode of expression this only means that he has changed his manner of thinking, and in changing, it might be for the better or it might be for the worse." He insisted that his own history was a case in point: "The several manners I have used in my art must not be considered as an evolution, or as steps toward an unknown ideal of painting. All I have ever made was made for the present." 31

Late in his life, Cézanne wrote to his friend and dealer Ambroise Vollard of his frustration:

I am working doggedly, for I see the promised land before me. Shall I be like the Hebrew leader or shall I be able to enter?...

I have made some progress. Why so late and with such difficulty? Is art really a priesthood that demands the pure in heart who must belong to it entirely? ${ }^{32}$

Picasso understood the importance of Cézanne's art not only for his own innovations, but for the advanced art of the early twentieth century in general: thus in 1943 he told a friend that Cézanne "was my one and only master... He was like a father to us all." ${ }^{33}$ Yet unlike Cézanne, for Picasso art was not a lifelong quest along a single path toward an unknown goal of the true style, but rather the expression of a series of ideas, often unrelated, using whatever means were appropriate. Declaring that "when I paint my object is to show what I have found and not what I am looking for," Picasso became a model for many later conceptual finders. ${ }^{34}$ In changing styles at will, he also became a prototype of a new form of conceptual artist, for whom style would not be a matter of integrity, but merely a convenient vehicle for expression.

\section{Generality of the Phenomenon}

The analysis presented above improves our understanding of the methods and art of 
Picasso, Polke, and Richter. Yet the significance of the analysis extends far beyond these three important artists - to other painters, to practitioners of other arts, and to those in other areas of intellectual activity.

Considering first other visual artists, versatility has been a characteristic of a number of the most important conceptual innovators of the twentieth century. A prime early example is Marcel Duchamp. In his 1913 book, The Cubist Painters, the poet and critic Guillaume Apollinaire began his treatment of Duchamp's work with a comment that parallels those of Schapiro, Campbell, and Danto, as he observed that "Marcel Duchamp has not yet painted enough pictures and his work is too varied for us to assess his true talent from the available evidence. ${ }^{{ }^{35}}$ Nearly a century later, the conceptual artist William Anastasi recalled that when he first saw a collection of Duchamp's art, "What struck me about it was not only that Duchamp's work was different from everybody else's, but that every Duchamp was so completely different from every other Duchamp." ${ }^{36}$ William Rubin declared of the period 1911-15, when Duchamp was in his mid-20s, that "No four years in the work of any other modern painter... witness so many radical departures in method and idea." Rubin understood that Duchamp could change his art so quickly and abruptly because of his conceptual approach: "Duchamp advances speculatively, not by painting but through cerebration; the finished work represents the plastic re-creation of a reality which has grown to maturity in the mind." ${ }^{37}$

Duchamp's variations occurred within a very different volume of output from that of Picasso, for unlike Picasso, who made many works within each of his adopted styles, Duchamp made very few works of art. Early in his career, the rejection of his Nude Descending a Staircase, No. 2 by the 1912 Salon des Indépendants, because the judges considered it an attack on Cubism, 
led Duchamp to the conclusion that that movement had grown dogmatic and rigid in just a few years, and prompted him to vow never to become set in his own taste. Because he reasoned that taste was a product of habit, he determined to avoid repetition. It was in view of this that he once remarked that "I've had thirty-three ideas; I've made thirty-three paintings." ${ }^{38}$ Late in his life, Duchamp claimed that his many abrupt changes stemmed from an attitude that he had shared with Francis Picabia, another conceptual painter who was his closest friend when the two were beginning their careers: "Fundamentally, I had a mania for change, like Picabia. One does something for six months, a year, and one goes on to something else. That's what Picabia did all his life." ${ }^{39}$ Duchamp was among the most protean of conceptual innovators, and his career was marked by the production of a series of works that had little in common other than their conceptual origins and their purpose of undermining basic conventions of Western art.

The painter Richard Hamilton, who was one of the key figures in developing English Pop art, in 1956 systematically constructed a collage, titled Just what is it that makes today's homes so different, so appealing?, that became a Pop icon and one of the most important works of art of the $20^{\text {th }}$ century. ${ }^{40}$ Yet he made no other works in the same style, and throughout his career Hamilton's art has been marked by extreme stylistic diversity. The English art historian Edward Lucie-Smith recognized the conceptual source of this diversity, observing that Hamilton's "productions tend to differ radically from one another because each is the embodiment of an idea and the idea itself has been allowed to dominate the material form. ${ }^{, 41}$ David Sylvester observed that Hamilton's development as an artist was marked by unpredictability, and explained that this was a product of the fact that his works were generally stylistic exercises, in which the subjects were dictated by Hamilton's continuing interest in understanding new styles: "he first gets 
interested in some form or other of visual communication and ... he then finds the sorts of subject-matter which suit that language or technique or method."42

David Hockney, the most important English painter of his generation, is a versatile conceptual artist who was brilliant early in his career. ${ }^{43}$ In 1962 , his final year as a student at London's Royal College of Art, for his entry in the school's student exhibition Hockney executed a series of four paintings, each in a different style, that he titled collectively Demonstrations of Versatility. Hockney later explained that "I deliberately set out to prove I could do four entirely different sorts of picture, like Picasso." He emphasized the point by giving each painting a subtitle that identified its style. ${ }^{44}$ A few years later, Hockney remarked that he often deliberately painted different parts of a single picture in different styles. ${ }^{45}$

Bruce Nauman is among the most influential artists alive today: as early as 1990, Peter Schjeldahl described him as "a maverick who at one time or another has affected the course of just about every visual medium except painting, earning a prestige among serious younger artists like that of no one else since Jasper Johns. ${ }^{, 46}$ Early in his career, Nauman was influenced by a retrospective exhibition of the work of Man Ray, a sometime collaborator of Duchamp's, who had worked variously as a painter, photographer, and film maker: "To me Man Ray seemed to avoid the idea that every piece had to take on a historical meaning. What I liked was that there appeared to be no consistency to his thinking, no one style." ${ }^{\prime 7}$ Throughout his career, Nauman has done conceptual work in a wide range of genres. Schjeldahl remarked that "Artists in the late 1960s were optimistic about the aesthetic potential of technologies and systems, and Nauman played with most of them - video, film, photography, light, sound, language, mathematics, holography, and more - to memorable effect. His work was Duchampian in its wit and insolence, 
in its teeming paradoxes, puns, and other forms of mental short-circuitry., ${ }^{\prime 8}$ One of Nauman's most celebrated early works, a photograph of himself spouting water from his mouth titled SelfPortrait as a Fountain, was a tribute to Duchamp's famous ready-made, Fountain. Nauman explained the diversity of his work by saying "I've never been able to stick to one thing." ${ }^{\text {"49 }}$ In a review of a Nauman retrospective in 1994, Michael Kimmelman observed that "His signature style is the lack of one... Even more than with Gerhard Richter or Sigmar Polke, you begin to understand Mr. Nauman only once you see the eclecticism."

Versatility has also been a characteristic of twentieth-century conceptual innovators in arts other than painting. A few significant examples can illustrate this. Ezra Pound was one of the most influential conceptual poets of the early twentieth century. He was famously precocious, as his early achievements included the invention of a new poetic doctrine, Imagism, at the age of 27. The critic Hugh Kenner remarked on the conceptual nature of the innovation: "The imagist... is not concerned with getting down the general look of the thing... The imagist's fulcrum... is the process of cognition itself. ${ }^{, 51}$ The literary historian Donald Stauffer remarked on the extraordinary diversity of Pound's work:

Taken as a whole, Pound's early poetry - published in five separate volumes between 1909 and 1915 [when Pound was 24-30 years old] - is an astonishing display of variety and versatility... [H]e wrote poems in a wide range of styles and modes: Catullan satire, Imagesque poems, Browningesque dramatic monologues, impressions, manifestoes, and translations from the Anglo-Saxon and Chinese. ${ }^{52}$

Pound's friend James Joyce was a conceptual innovator in fiction. One obituarist described Joyce as "the great research scientist of letters, handling words with the same freedom and originality that Einstein handles mathematical symbols," and observed that "even the 
strongest of his characters seems dwarfed by the great apparatus of learning that he brings to bear on them.. ${ }^{, 53}$ In Ulysses, the most influential novel of the twentieth century, Joyce deliberately used different styles in different chapters. The critic Edna O'Brien remarked that the styles were "so variable that the eighteen episodes could really be described as eighteen novels between the one cover." 54 The surprising juxtapositions of styles in Ulysses led the French critic Pierre Courthion to compare the book to the work of Picasso. ${ }^{55}$ Terry Eagleton observed that "Ulysses is an enormous repertoire of 'packaged' styles and discourses, no one of which is absolute." Considering Joyce's ocuvre as whole, Eagleton posed the question "What... is James Joyce's style?," and reflected that "The question is almost impossible to answer, as it is not in the case of Jane Austen or William Faulkner.” Eagleton recognized that Joyce's writing did not have the consistency of these two experimental authors: "His writing is motley, hybrid, mongrelized, a thing of shreds and patches. Words are shot through with other words, one style is bounced off another, one language folded within a second." 56

Five decades after Ulysses, Thomas Pynchon, another conceptual innovator, published a novel that is frequently compared to Joyce's masterpiece. ${ }^{57}$ One scholar remarked that "the prose style of Gravity's Rainbow is not a single style but an impressive compendium of many styles which contribute considerable power to the paradox within the novel," while another observed that the book's narrative styles range "from Kabbalistic revelation, to formulaic romance, to folkmyth, to cinematic parody, to comic book classic, to technological manual, to sewer fantasy, to rocket graffiti." ${ }^{, 5}$ In a review of Gravity's Rainbow, Richard Poirier declared that "At thirty-six, Pynchon has established himself as a novelist of major historical importance." $" 59$

When a friend told John Cage that he planned to lecture on his musical style, Cage 
replied, "You have a problem - there are so many." ${ }^{60}$ Cage is known for the diversity of his many innovations, including the prepared piano, compositional techniques that incorporate chance, and his work 4'33", in which a pianist sat for that length of time without touching the keyboard. ${ }^{61}$ Cage was prompted to write the latter when his friend Robert Rauschenberg exhibited his white paintings, a series of panels with no images, that changed in appearance as shadows or reflections moved across them. Just as Rauschenberg's paintings were intended to demonstrate that there was no such thing as an empty canvas, Cage's composition proved that sounds are always present. ${ }^{62}$ Cage was a conceptual innovator, who consistently worked to expand the boundaries of music, and who was committed to radical change: "If my work is accepted, I must move on to the point where it isn't." His answer to a question about his philosophy was a self-reflexive pun:

"Get out of whatever cage you find yourself in." ${ }^{63}$ Cage devoted much of his career to a variety of approaches to a goal that was not aural but conceptual, of "giving up control" over music, "so that sounds can be sounds." ${ }^{64}$ John Rockwell concluded that

Cage's music has undergone shifts of style and emphasis, as with almost all composers. In his case, though, the shifts have been radical ones, complete transformations of method, performing forces and sheer sound. What has remained constant is his questing spirit of adventure, his determination to seem fresh and even outrageous, and his meditative epistemology. ${ }^{65}$

In 1968, the film critic Manny Farber began an essay about Jean-Luc Godard by stressing the diversity of the director's movies:

Each Godard film is of itself widely varied in persona as well as quality. Printed on the blackboard of one of his Formicalike later films, hardly to be noticed, is a list of African animals: giraffe, lion, hippo. At the end of this director's career, there will probably be a hundred films, each one a bizarrely different species, with its own excruciatingly singular skeleton, tendons, plumage... Unlike 
Cézanne, who used a three-eighths-inch square stroke and nervously exacting line around every apple he painted, the form and manner of execution changes totally with each film.

Farber recognized that the diversity of Godard's films was a product of the director's conceptual approach:

Braining it out before the project starts, most of the invention, the basic intellectual puzzle, is pretty well set in his mind before the omnipresent [cinematographer Raoul] Coutard gets the camera in position... Each of his pictures presents a puzzle of parts, a unique combination of elements to prove a preconceived theory. ${ }^{66}$

Three decades later, the critic Peter Wollen observed that Godard had made an additional 50 films since Farber had written his essay, and declared that "just as Farber predicted, each film seems to be sui generis, quite unlike any of his previous work, the same only in being so unpredictably, inconsistently different." In Godard's constant quotation from old Hollywood films and his equally consistent disregard for all of the conventions of those films, Wollen recognized a key characteristic of the conceptual artist, who borrows the techniques of his predecessors but often transforms them for uses that would appall those earlier practitioners: "Godard's films showed a contradictory reverence for the art of the past and delinquent refusal to obey any of its rules." ${ }^{97}$ Godard himself consistently maintained that film was simply one means for expressing his ideas: "I think of myself as an essayist... only instead of writing, I film them. Were the cinema to disappear, I would simply accept the inevitable and turn to television; were television to disappear, I would revert to pencil and paper. For there is a clear continuity between all forms of expression. It's all one." ${ }^{, 68}$

It also appears that the most versatile practitioners of academic disciplines are conceptual scholars. More research remains to be done before this can be considered to be firmly 
established, but study of the careers of Nobel laureates in economics provides impressive evidence of the ability of some conceptual scholars to change their areas of study rapidly and frequently. One archetypal example of a versatile conceptual economist, Kenneth Arrow, must rank among the most protean social scientists of the twentieth century. His most important contributions are remarkably varied in technique, and treat such diverse subjects as the theory of social choice, general equilibrium theory, the implications of risk aversion for medical insurance, optimal social investment policies, the theory of learning by doing, and the constant elasticity of substitution production function.

\section{Conclusion}

Conceptual innovators pose specific problems, and solve them. Their recognition that they have reached a goal can free them to pursue another one: that project is finished, their curiosity about it is satisfied, and they can go on to something else, perhaps completely different. This behavior is logical and reasonable to the conceptual artist, but is problematic from the vantage point of his experimental counterpart. Experimental innovators' problems are generally broader, their goals less distinct. They are rarely satisfied that they have reached their goals, and many in fact come to doubt that their goals can be reached at all: the more they progress, the more distant their goal appears. Their persistent dissatisfaction with their efforts, and their skepticism about the possibility of conclusive resolution of artistic goals, lead them to question the commitment and sincerity of any artist who changes styles, and goals, with any frequency.

Interestingly, recognition of the versatility of a number of important conceptual innovators in art during the past century adds a dimension to our appreciation of the significance of Picasso. Some of the greatest artists of the past influenced other artists not only through their 
innovations in style, but by providing new models of how artists create their work. So for example the greatness of Raphael and Titian is due not solely to their innovations in composition, form, and color, but also to the fact that Raphael inspired generations of conceptual painters with his meticulous planning of his canvases, and that Titian equally inspired generations of experimental painters with his unplanned direct approach to painting, and the repeated revisions by which he brought his works to completion. ${ }^{69}$ In light of the present investigation, it appears similarly that Picasso's greatness lies not only in his formal innovations, but also in his creation of a new model of artistic behavior, the versatile conceptual artist who makes frequent and precipitous changes in the style and form of his work. In 1943, when a visitor to Picasso's studio remarked that a statue Picasso had made from a child's scooter was not really a sculpture, Picasso exclaimed: "What is sculpture? What is painting? Everyone's still clinging to outdated ideas, obsolete definitions, as if the artist's role was not precisely to offer new ones."70 It was this realization, that artists could innovate freely and often, that made Picasso a prototype of the versatile conceptual innovator.

The parallel observations of Meyer Schapiro on Picasso, David Campbell on Polke, and Arthur Danto on Richter clearly demonstrate the dangers that attend the neglect of a comparative approach in the analysis of art - a neglect that is not only widespread, but is actually celebrated by many contemporary humanists. These art scholars' surprise at the practices of these painters is a consequence of their failure to recognize that the practices are common among a class of artists, those I call conceptual. And the scholars' questions about the artists' integrity of purpose are equally a consequence of their failure to understand the systematic differences that exist in the practices and attitudes of conceptual and experimental artists. More specifically, art historians' 
failure to recognize the common basis of the behavior of versatile conceptual innovators has resulted in an incomplete understanding of the practices of some of the most influential innovators of the past century, including Marcel Duchamp, Francis Picabia, Joseph Beuys, Robert Rauschenberg, Yves Klein, David Hockney, Bruce Nauman, Jeff Koons, and Damien Hirst. We should also expect more names to be added to this list in future, because of the heavy emphasis on conceptual innovation in the contemporary art world.

Just as social scientists should become more aware of the value of studying the behavior of individual innovators, humanists must devote greater attention to recognizing and understanding common patterns in the practices of classes of individuals. The rewards for both of these changes in practice may be considerable, for they may allow us to gain a greater understanding of human creativity in all the domains where it occurs. 
$\underline{\text { Footnote }}$

I thank Robert Jensen, Joshua Kotin, Roger Myerson, and Hugo Sonnenschein for discussions of the issues treated in this paper.

1. Christina Duff, "In Payscales, Life Sometimes Imitates Art," Wall Street Journal (May 22, 1998), p. B1.

2. Scott Mclemee, "Of Canvases and Coefficients," Chronicle of Higher Education (April 19, 2002), p. A21.

3. Meyer Schapiro, The Unity of Picasso’s Art (New York: George Braziller, 2000), p. 1.

4. David Campbell, "Plotting Polke," in David Thistlewood, ed., Sigmar Polke (Liverpool: Liverpool University Press, 1996), p. 19.

5. Arthur Danto, Unnatural Wonders (New York: Farrar, Straus, Giroux, 2005) p. 182.

6. Schapiro, The Unity of Picasso's Style, p. 5.

7. Campbell, "Plotting Polke," p. 19.

8. Danto, Unnatural Wonders, p. 182.

9. David Galenson, Painting Outside the Lines (Cambridge: Harvard University Press, 2001), p. 51.

10. E.g. see George Heard Hamilton, Painting and Sculpture in Europe, 1880-1940 (Harmondsworth: Penguin, 1967), p. 237.

11. John Berger, Selected Essays (New York: Vintage Books, 2001), pp. 72, 82, 84.

12. Thistlewood, Sigmar Polke, pp. 46-49.

13. Robert Storr, Gerhard Richter (New York: Museum of Modern Art, 2002).

14. John Golding, Cubism (London: Faber and Faber, 1959), p. 60.

15. Gerhard Richter, The Daily Practice of Painting (Cambridge: MIT Press, 1995), pp. 78, $30,130$.

16. Tut Schlemmer, ed., The Letters and Diaries of Oskar Schlemmer (Middletown, CT: Wesleyan University Press, 1972), p. 102.

17. Marilyn McCully, ed., A Picasso Anthology (Princeton: Princeton University Press, 1982), pp. 147-48. 
18. For a general definition of experimental art see Galenson, Painting Outside the Lines, Chapter 5.

19. Thistlewood, Sigmar Polke, p. 2.

20. On the experimental basis of Abstract Expressionism, see Galenson, Painting Outside the Lines, pp. 118-28.

21. McCully, A Picasso Anthology, p. 145.

22. McCully, A Picasso Anthology, p. 170.

23. John Berger, The Success and Failure of Picasso (New York: Vintage Books, 1989), pp. 35-36.

24. Pierre Cabanne, Pablo Picasso (New York: William Morrow, 1977), p. 272.

25. Schapiro, The Unity of Picasso's Art, p. 2.

26. Schapiro, The Unity of Picasso's Art, p. 29.

27. Jack Flam, Matisse and Picasso (Cambridge, MA: Westview, 2004), p. 122.

28. Schapiro, The Unity of Picasso's Art, p. 7.

29. Flam, Matisse and Picasso, p. 125.

30. David Sylvester, About Modern Art (New York: Henry Holt, 1997), p. 30.

31. Alfred Barr, Picasso (New York: Museum of Modern Art, 1946), pp. 270-71.

32. John Rewald, ed., Paul Cézanne Letters (New York: Da Capo Press, 1995), pp. 293-94.

33. Brassaï, Conversations with Picasso (Chicago: University of Chicago Press, 1999), p. 107.

34. Barr, Picasso, p. 270.

35. Guillaume Apollinaire, The Cubist Painters (Berkeley: University of California Press, 2004), p. 73.

36. Thomas McEvilley, The Triumph of Anti-Art (Kingston, NY: McPherson and Company, 2005), p. 105.

37. Joseph Masheck, ed., Marcel Duchamp in Perspective (Englewood Cliffs, NJ: PrenticeHall, 1975), p. 43. 
38. McEvilley, The Triumph of Anti-Art, pp. 20, 28.

39. Pierre Cabanne, Dialogues with Marcel Duchamp (New York: Da Capo Press, 1987), p. 37.

40. David Galenson, "The Most Important Works of Art of the $20^{\text {th }}$ Century," (unpublished paper, University of Chicago, 2006).

41. Nikos Stangos, ed., Concepts of Modern Art, third ed., (New York: Thames and Hudson, 1997), p. 230.

42. Sylvester, About Modern Art, pp. 283, 286.

43. Galenson, Painting Outside the Lines, p. 188.

44. Marco Livingstone, David Hockney (London: Thames and Hudson, 1996), p. 41.

45. Kristine Stiles and Peter Selz, eds., Theories and Documents of Contemporary Art (Berkeley: University of California Press, 1996), p. 228.

46. Peter Schjeldahl, The “7 Days” Art Columns, 1988-1990 (Great Barrington, MA: The Figures, 1990), p. 198.

47. Coosje van Bruggen, Bruce Nauman (New York: Rizzoli, 1988), p. 14.

48. Robert Morgan, ed., Bruce Nauman (Baltimore: Johns Hopkins University Press, 2002), p. 191.

49. Morgan, Bruce Nauman, p. 239.

50. Morgan, Bruce Nauman, p. 209.

51. Hugh Kenner, The Poetry of Ezra Pound (Lincoln: University of Nebraska Press, 1985), p. 73.

52. Donald Stauffer, A Short History of American Poetry (New York: E. P. Dutton, 1974), p. 259.

53. Robert Deming, ed., James Joyce: The Critical Heritage, Vo. 2 (New York: Barnes and Noble, 1970), p. 747.

54. Edna O’Brien, James Joyce (New York: Penguin, 1999), p. 97.

55. Pierre Courthion, Le Visage de Matisse (Lausanne: Marguerat, 1942), pp. 92-93.

56. Terry Eagleton, The English Novel (Oxford: Blackwell, 2005), p. 288. 
57. E.g. see Edward Mendelson, ed., Pynchon (Englewood Cliffs: Prentice-Hall, 1978), pp. 56, 172; Richard Pearce, ed., Critical Essays on Thomas Pynchon (Boston: G. K. Hall, 1981), p. 170; Brian Stonehill, The Self-Conscious Novel: Artifice in Fiction from Joyce to Pynchon (Philadelphia: University of Pennsylvania Press, 1988), p. 146.

58. Stonehill, The Self-Conscious Novel, p. 149; Mendelson, Pynchon, p. 193.

59. Mendelson, Pynchon, p. 167.

60. David Revill, The Roaring Silence (New York: Arcade Publishing, 1992), p. 5.

61. James Pritchett, The Music of John Cage (Cambridge: Cambridge University Press, 1993).

62. Richard Kostelanetz, ed., Writings About John Cage (Ann Arbor: University of Michigan Press, 1993), p. 128.

63. Revill, The Roaring Silence, p. 13.

64. David Nicholls, ed., The Cambridge Companion to John Cage (Cambridge: Cambridge University Press, 2002), p. ix.

65. John Rockwell, All American Music (New York: Alfred A. Knopf, 1983), pp. 50-51.

66. Manny Farber, Negative Space, expanded edition (New York: Da Capo Press, 1998), p. 259.

67. Peter Wollen, Paris Hollywood (London: Verso, 2002), pp. 80-81, 77.

68. Jean-Luc Godard, Godard on Godard (New York: Da Capo Press, 1972), p. 171.

69. E.g. see Ernst van de Wetering, Rembrandt (Berkeley: University of California Press, 2000), pp. 162-69; Robert Jensen, “Anticipating Artistic Behavior: New Research Tools for Art Historians," Historical Methods, Vol. 37, No. 3 (2004), pp. 137-53.

70. Brassaï, Conversations with Picasso, p. 69. 
Table 1: Percentage Distributions of Textbook Illustrations over Artists' Careers

\begin{tabular}{|l|c|c|c|c|c|c|c|c|c|}
\hline Age & $20-9$ & $30-9$ & $40-9$ & $50-9$ & $60-9$ & $70-9$ & $80-9$ & $90-9$ & Total \\
\hline \hline$\underline{\text { Artist }}$ & & & & & & & & & \\
Picasso & 35 & 25 & 17 & 14 & 4 & 2 & 2 & 1 & 100 \\
\hline Polke & 67 & 7 & 19 & 7 & 0 & - & - & - & 100 \\
\hline Richter & 0 & 40 & 7 & 47 & 6 & 0 & - & - & 100 \\
\hline
\end{tabular}

Source: Picasso: David Galenson, "The Greatest Artists of the Twentieth Century," NBER Working Paper 11899, Table 5.

Polke and Richter: Cory Bell, Modern Art (New York: Watson-Guptill, 2000); Jonathan Fineberg, Art Since 1940, second ed. (New York: Harry N. Abrams, 2000); David Hopkins, After Modern Art, 1945-2000 (Oxford: Oxford University Press, 2000); Martin Kemp, ed., The Oxford History of Western Art (Oxford: Oxford University Press, 2000); Bernard Blistène, A History of $20^{\text {th }}$-Century Art (Paris: Flammarion, 2001); Edward Lucie-Smith, Movements in Art Since 1945, new ed. (London: Thames and Hudson, 2001); Klaus Richter, Art (Munich: Prestel, 2001); Michael Archer, Art Since 1960, new ed. (London: Thames and Hudson, 2002); Amy Dempsey, Art in the Modern Era (New York: Harry N. Abrams, 2002); Hugh Honour and John Fleming, The Visual Arts: A History, sixth ed. (New York: Harry N. Abrams, 2002); H. H. Arnason, A History of Modern Art, fifth ed. (Upper Saddle River, NJ: Prentice Hall, 2004); Sam Hunter, John Jacobus, and Daniel Wheeler, Modern Art, third ed. (New York: Vendome Press, 2004); Pascale Le Thorel-Daviot, Nouveau Dictionnaire des Artistes Contemporains (Paris: Larousse, 2004); Gill Perry and Paul Wood, eds., Themes in Contemporary Art (New Haven: Yale University Press, 2004); Hal Foster, Rosalind Krauss, Yve-Alain Bois, and Benjamin Buchloh, Art Since 1900 (New York: Thames and Hudson, 2004);Ingo

Walther, ed., Art of the 20 ${ }^{\text {th }}$ Century, 2 vols. (Cologne: Taschen, 2005). 